\title{
Effects of Non-meat Protein Binders and Acidification on the Efficiency of Cold-Set Pork Restructuring by High Pressure
}

\author{
Geun-Pyo Hong ${ }^{1}$, Ji-Yeon Chun ${ }^{1}$, Si-Kyung Lee, and Mi-Jung Choi* \\ Department of Molecular Biotechnology, Konkuk University, Seoul 143-701, Korea \\ ${ }^{1}$ Department of Food Science and Biotechnology of Animal Resources, Konkuk University, Seoul 143-701, Korea
}

\begin{abstract}
We investigated the effects of non-meat protein binders combined with glucono- $\delta$-lactone (GdL) on the binding properties regarding restructured pork prepared by high-pressure treatment. Soy protein isolate (SPI), casein (CS), whey protein concentrate (WPC), and egg white (EW) were used as non-meat protein binders and compared with the control (no binder) and with the $\kappa$-carrageenan $(\mathrm{KC})$ treatment. The compression and depression rates were 2.3 and $37 \mathrm{MPa} / \mathrm{s}$, respectively, and pressurization was conducted at $200 \mathrm{MPa}$ for $30 \mathrm{~min}$ at $4^{\circ} \mathrm{C}$. After pressurization, the physical properties $(\mathrm{pH}$, water-holding capacity, color, tensile strength, and microscopic structure) of the sample were evaluated. The combination of pressurization with acidification enabled cold-set meat binding, and the binding strength of restructured pork was enhanced by the addition of non-meat proteins. Among binders, SPI demonstrated the best efficiency in binding meat pieces. Therefore, the present study demonstrated that the combination of acidification and pressurization processes with the utilization of non-meat protein binders has a potential benefit in meat restructuring.
\end{abstract}

Key words: non-meat protein, restructured meat, pressurization, acidification, meat binding

\section{Introduction}

It is well known that proteins undergo aggregation and gelation depending on environmental conditions such as $\mathrm{pH}$ and temperature. Protein gel formation is important for the texturization of semi-solid food products, including tofu, cheese, and sausages. Among proteins, myofibrillar proteins (MPs) are likely to be more labile in response to environmental changes than plant proteins, owing to differences in structure and thermal stability. Texturization of meat products is most depends on the gel-forming ability of MPs. To form an MP gel, various techniques have been introduced. Microbial transglutaminase-catalyzed cross-linking is one of major examples of non-thermal meat gelation (Chin et al., 2009). Protein oxidation also enables cross-linking of proteins, thereby forming an irreversible polymer; however, the oxidative process coincides precisely with functional and nutritional losses of proteins (Xiong, 2000). Ngapo et al.

\footnotetext{
*Corresponding author: Mi-Jung Choi, Department of Molecular Biotechnology, Konkuk University, Seoul 143-701, Korea. Tel: 82-2-450-3048, Fax: 82-2-455-1044, E-mail: choimj@konkuk. ac.kr
}

(1996) reported that a cold-set MP gel could be obtained by glucono- $\delta$-lactone (GdL)-induced slow acidification.

High-pressure treatment, an analogue of thermal treatment, induces protein unfolding, thereby promoting protein gelation. For pressurization of fresh meat, the physical and structural changes of proteins manifests partial unfolding and denaturation, and meat protein denaturation affects the functional properties and color of meat. Alternately, pressure-induced structural changes in proteins (aggregation and gelation), namely cold-set meat restructuring or reforming, provide a possibility to bind meat pieces without thermal treatment. In a preliminary study, cold-set meat restructuring could not be achieved by pressurization at $200 \mathrm{MPa}$ for $30 \mathrm{~min}$, and the addition of non-meat protein binders was of no use to bind meat pieces unless the sample was subjected to thermal treatment (Hong et al., 2006). Effective cold-set meat binding was achieved under the same pressure conditions by using K-carrageenan (KC). On pressurization, $\mathrm{KC}$ formed a continuous network-like structure inside the saltextracted MP network, and the simultaneous addition of GdL resulted in better integrity of the MP network structure, leading to high tensile strength in the restructured meat (Hong et al., 2008). 
In general, commercial food proteins are mainly produced by spray drying, and the proteins show poor functionalities because of partial or complete denaturation. In meat product formulations, however, the use of denatured non-meat protein ingredients is a better way to improve the textural and rheological properties of the products, because structural unfolding of globular proteins manifests as a filamentous structure on re-heating (Bryant and MaClements, 1998; Feng and Xiong, 2002). Consequently, the filamentous structure of non-meat proteins can form a network with the MP network. These heterologous protein networks were formed only under thermal treatment, and not under pressurization at $200 \mathrm{MPa}$ (Hong et al., 2006). On the other hand, GdL is an effective protein-gelling ingredient, and some studies have reported that preheat-treated milk or soy proteins were more susceptible to acid gelation than their native forms (Bringe and Kinsella, 1990; Dybowska and Fujio, 1998). Thus, it was expected that the use of GdL combined with protein-based binders might eliminate the drawback of insufficient cold-set meat binding observed in our previous study (Hong et al., 2006, 2008). The present study explored the effects of non-meat proteins combined with GdL on the efficiency of meat restructuring after high-pressure treatment.

\section{Materials and Methods}

\section{Materials}

Pork loin (longissimus dorsi) was obtained from 6 carcasses at $48 \mathrm{~h}$ post-mortem ( $\mathrm{pH} 5.72 \pm 0.04$ ). Meat was frozen at $-30^{\circ} \mathrm{C}$ prior to sample preparation (within 3 weeks). Commercially produced non-meat proteins, including soy protein isolate ( $80.6 \%$ protein), milk casein (sodium salt, $90.8 \%$ protein), whey protein concentrate (81.3\% protein), and egg white powder $(82.2 \%$ protein), were donated by Sam-Hwa Asia Co. (Korea). K-carrageenan $(\kappa \mathrm{C})$ was purchased from Sigma-Aldrich Co (USA). All chemicals used in the present study were analytical grade.

\section{Sample treatment}

Two pork loins for each batch were thawed at $4^{\circ} \mathrm{C}$ for $48 \mathrm{~h}$, and all visible fat and connective tissue was trimmed. Meat was cut into $1-\mathrm{cm}$ cubes, and the cubes from 2 different loins were mixed together. The meat cubes $(300 \mathrm{~g}$ per treatment) were hand-mixed with $0.5 \% \mathrm{NaCl}$ and $0.3 \%$ sodium tripolyphosphate for $2 \mathrm{~min}$, then $0.5 \%$ glucono- $\delta$-lactone (GdL) and $1 \%$ binders were added and hand-mixed for $3 \mathrm{~min}$ (Table 1). Soy protein isolate (SPI),
Table 1. Formulation of restructured pork made with or without non-meat protein binders

\begin{tabular}{lcc}
\hline \hline \multirow{2}{*}{ Ingredients } & \multicolumn{2}{c}{ Formulation $(\mathrm{g} / 300 \mathrm{~g}$ batch $)$} \\
\cline { 2 - 3 } & Control & Treatments \\
\hline Pork loin cubes & 296.1 & 293.1 \\
$\mathrm{NaCl}$ & 1.5 & 1.5 \\
Sodium tripolyphosphate & 0.9 & 0.9 \\
Glucono- $\delta$-lactone & 1.5 & 1.5 \\
Binder $^{1)}$ & - & 3.0 \\
\hline
\end{tabular}

${ }^{1)}$ Binders used in this study contained $\kappa$-carrageenan, soy protein isolate, casein, whey protein concentrate, and egg white.

casein (CS), whey protein concentrate (WPC), and egg white (EW) were used as non-meat protein binders and compared with $\mathrm{K}$-carrageenan as a non-protein binder. In the control (C), $1 \%$ binder was substituted with the same amount of meat cubes. The mixture was filled into fibrous casing ( $4.5 \mathrm{~cm}$ diameter) and vacuum-packed in a poly nylon pouch. The mixture was kept at $4^{\circ} \mathrm{C}$ for $24 \mathrm{~h}$ to allow sufficient acidification and pressurized using a lab-scale hydrostatic pressure system (1-L working volume) as described previously (Hong et al., 2008). Ethanol was used as the pressure-transmitting medium. The compression and depression rates were 2.3 and $37 \mathrm{MPa} / \mathrm{s}$, respectively, and pressurization was performed at 200 $\mathrm{MPa}$ for $30 \mathrm{~min}$ at $4^{\circ} \mathrm{C}$. After pressurization, the physicochemical properties of the sample were estimated without further storage. All procedures were repeated 3 times on different days $(\mathrm{n}=3)$.

\section{pH}

The $\mathrm{pH}$ of the sample was determined using a $\mathrm{pH}$ meter (pH 900, Precisa Co., Switzerland). Approximately $5 \mathrm{~g}$ of sample was homogenized with $20 \mathrm{~mL}$ of distilled water at 10,000 rpm for $2 \mathrm{~min}$ by using an SMT process homogenizer (SMT Co. Ltd., Japan), and the $\mathrm{pH}$ was determined in duplicate.

\section{Water binding properties}

The moisture content of samples was determined in triplicate by the method described by the AOAC (1990). Expressible moisture was determined by applying centrifugal force. Approximately, $1 \mathrm{~g}$ of sample $\left(M_{\text {Meat }}\right)$ was placed in a centrifuge tube along with gauze as moisture absorbent. After centrifuging at 1,000 $\mathrm{g}$ for $10 \mathrm{~min}$ using RC-3 centrifuge (Sorvall Co., Thermo Scientific, USA), absorbed moisture in the absorbent before $\left(M_{1}\right)$ and after drying $\left(M_{2}\right)$ was measured. The expressible moisture was expressed as a percentage of exudative loss over initial sample weight as follows. All measurements were carried 
out in triplicate.

Expressible moisture $(\%)=\frac{M_{1}-M_{2}}{M_{\text {Meat }}} \times 100$

\section{Instrumental color}

The sample was sliced to a thickness of $1 \mathrm{~cm}$ and kept at ambient temperature for $10 \mathrm{~min}$. The color of the sample surface was randomly measured 6 times by using a color reader (CR-10, Konica Minolta Sensing, Inc., Japan) calibrated with a white standard plate $\left(L^{*}=97.83\right.$, $\left.a^{*}=-0.43, b^{*}=+1.98\right)$. The CIE $L^{*}, a^{*}$, and $b^{*}$ values were determined as indicators of lightness, redness, and yellowness, respectively. The total color difference $(\Delta E)$ was calculated using the following equation on the basis of the color differences between treated samples and raw pork $\left(L^{*}=48.9, a^{*}=12.4, b^{*}=9.7\right)$.

$$
\Delta E=\sqrt{\Delta L^{* 2}+\Delta a^{* 2}+\Delta b^{* 2}}
$$

\section{Tensile strength}

The sample was sliced to a thickness of $1 \mathrm{~cm}$ and cut into rectangular forms $(1 \times 1 \times 4 \mathrm{~cm})$ and was fixed at $1 \mathrm{~cm}$ from each end by using 3 pins connected to the plate and the plunge, respectively (Hong et al., 2008). The force required to pull apart the sample was measured using a digital gauge (DPS-20, IMADA Co., Japan) at a head speed of $60 \mathrm{~mm} / \mathrm{min}$. The tensile strength of each treatment was determined 12 times.

\section{Scanning electron microscopy}

The sample was sliced to a thickness of $2 \mathrm{~mm}$ and cut into $1-\mathrm{cm}$ squares. Sample was frozen at $-75^{\circ} \mathrm{C}$ for $24 \mathrm{~h}$ and lyophilized at 0.6 torr for $48 \mathrm{~h}$. The sample was goldcoated using an ion sputter (E-1010, Hitachi Science System Ltd., Japan), and the microstructure near the junction zone was observed using a scanning electron microscope (S-3000 N, Hitachi Science System Ltd., Japan) at $\times 200$ and $\times 1,000$ magnifications with an accelerating voltage of $25 \mathrm{kV}$.

\section{Statistical analysis}

A completely randomized block design was adopted, and the data were analyzed by the general linear model procedure by using the SAS program (ver. 9.1; SAS Institute Inc., Cary, USA). One-way analysis of variance (ANOVA) was conducted with the means of 3 different batches $(n=$ 3), and the means were ranked by Fisher's Least Significant Difference (LSD) test when the main effect (treatment) was significant at the 95\% level $(p<0.05)$.

\section{Results and Discussion}

\section{pH and water-binding properties}

As shown in Table 2, the final $\mathrm{pH}$ of the samples after pressurization was about 5.4-5.5, which was in accordance with our previous study (Hong et al., 2008). All binder treatments resulted in a higher $\mathrm{pH}$ than that of the control $(p<0.05)$, with the exception of CS treatment. Nevertheless, variations in $\mathrm{pH}$ between treatments were small $(<0.04 \mathrm{pH}$ unit), and the final $\mathrm{pH}$ of restructured pork might be mainly influenced by the addition of GdL (Ngapo et al., 1996). It should be noted that pressurization increases the $\mathrm{pH}$ of the meat (Hong et al., 2008). It is widely recognized that $\mathrm{pH}$ is crucial for the yield of the final meat product, and the lower the $\mathrm{pH}$ of the meat product, the greater the moisture loss (Aaslyng, 2002). Hong et al. (2008) reported that the moisture content of restructured pork prepared by pressurization at $200 \mathrm{MPa}$ was similar at varying GdL concentrations, although the GdL concentration significantly influenced the waterholding capacity of the products. In the current study, the moisture content of restructured pork showed differences among treatments $(p<0.05)$, and the overall moisture content was $71-73 \%$, compared to $73.2 \%$ of raw pork material (data not shown). Although the relationship between pressurization and the water binding ability of meat is not fully understood, it is widely accepted that pressurized meat shows better water-binding properties than untreated meat. According to the classical perspective, the waterbinding ability of meat is dependent on the space between the muscle fibers, which is regulated by muscle $\mathrm{pH}$ (Hamm, 1986). Upon mild pressurization ( $200 \mathrm{MPa})$, structural changes in proteins are driven by the penetration of water molecules into the cavities of the proteins (Boonyaratanakornkit et al., 2002). The penetration of water molecules

Table 2. pH and water binding properties of restructured pork prepared with various binders, glucono- $\delta$-lactone, and pressurization at $200 \mathrm{MPa}$ for $30 \mathrm{~min}$

\begin{tabular}{cccr}
\hline \hline Treatment $^{1)}$ & $\mathrm{pH}$ & Moisture (\%) & \multicolumn{1}{c}{ EM $(\%)^{2)}$} \\
\hline $\mathrm{C}$ & $5.44 \pm 0.02^{\mathrm{c}}$ & $72.7 \pm 0.08^{\mathrm{a}}$ & $14.3 \pm 0.53^{\mathrm{a}}$ \\
$\mathrm{KC}$ & $5.51 \pm 0.02^{\mathrm{ab}}$ & $72.2 \pm 0.29^{\mathrm{b}}$ & $9.1 \pm 0.81^{\mathrm{b}}$ \\
$\mathrm{SPI}$ & $5.52 \pm 0.03^{\mathrm{a}}$ & $70.6 \pm 0.46^{\mathrm{c}}$ & $11.1 \pm 0.42^{\mathrm{b}}$ \\
$\mathrm{CS}$ & $5.47 \pm 0.03^{\mathrm{bc}}$ & $70.4 \pm 0.80^{\mathrm{c}}$ & $11.0 \pm 1.92^{\mathrm{b}}$ \\
WPC & $5.50 \pm 0.02^{\mathrm{ab}}$ & $71.7 \pm 0.60^{\mathrm{b}}$ & $9.9 \pm 0.38^{\mathrm{b}}$ \\
EW & $5.53 \pm 0.02^{\mathrm{a}}$ & $71.6 \pm 0.51^{\mathrm{b}}$ & $10.2 \pm 1.23^{\mathrm{b}}$ \\
\hline
\end{tabular}

${ }^{1)} \mathrm{C}$, control; $\mathrm{KC}, \mathrm{K}$-carrageenan; $\mathrm{SPI}$, soy protein isolate; $\mathrm{CS}$, casein; WPC, whey protein concentrate; EW, egg white.

${ }^{2)} \mathrm{EM}$, expressible moisture

${ }^{\mathrm{a}-\mathrm{c}}$ Means with different superscripts within same column are significantly different $(p<0.05)$. 
into the protein interior triggers the disruption of interactions maintaining or stabilizing the tertiary and quaternary structures of the proteins (Boonyaratanakornkit et al., 2002; Knorr et al., 2006). As a result, proteins are partially unfolded (molten globule state) under high pressure; this presumably causes the high final $\mathrm{pH}$ and high water binding ability of meat.

All binder treatments resulted in lower moisture content than in the control $(p<0.05)$, probably resulting from the different formulations (with and without binders). The actual water binding ability of the protein binders was revealed by the measurements of expressible moisture; binder-treated meat had lower expressible moisture than control $(p<0.05)$. In addition, the moisture content of WPC- and EW-treated meat was higher than those of SPI- and CS-treated meat $(p<0.05)$, but not with $\mathrm{KC}$ treatment. In contrast to the poor hydration of thermaltreated SPI and SC (Shen, 1976; Vasbinder et al., 2004) samples, those treated with WPC and EW were reported to retain hydration ability after thermal treatment (Campbell et al., 2003; Vasbinder et al., 2004), as evidenced by their different moisture contents after pressurization. However, binder types presumably had only a minor effect on water-binding properties since there were no differences in the expressible moisture with different binder treatments.

\section{Tensile strength}

The efficiency of meat restructuring relies on the binding strength (expressed as the tensile strength) of meat pieces. Cold-set meat binding could be achieved with $0.5 \% \mathrm{GdL}$ (control), but the binding strength was $0.97 \mathrm{~N}$; this value of tensile strength was not high enough to allow handling of the sample without having it break up easily into pieces (Fig. 1). Although it is difficult to quantify an acceptable tensile strength, Kuraish et al. (1997) suggested around $1.6 \mathrm{~N}\left(\sim 80 \mathrm{~g} / \mathrm{cm}^{2}\right)$ of tensile strength as an acceptable value, which would allow the handling of raw restructured meat. In the present study, all binder treatments resulted in a higher tensile strength than control $(p<0.05)$, but an acceptable tensile strength (ca $1.6 \mathrm{~N}$ ) was achieved with the KC and SPI treatments. We have previously demonstrated the efficiency of $\mathrm{KC}$ as a coldset meat binder upon pressurization (Hong et al., 2008). In combination with acidification, however, SPI had better meat-binding ability than $\mathrm{KC}$ after depression $(p<0.05)$. It is well known that SPI is composed mainly of globulins and albumins, and that soy globulins (glycinin and $\beta$-conglycinin) are key proteins related to protein aggregation

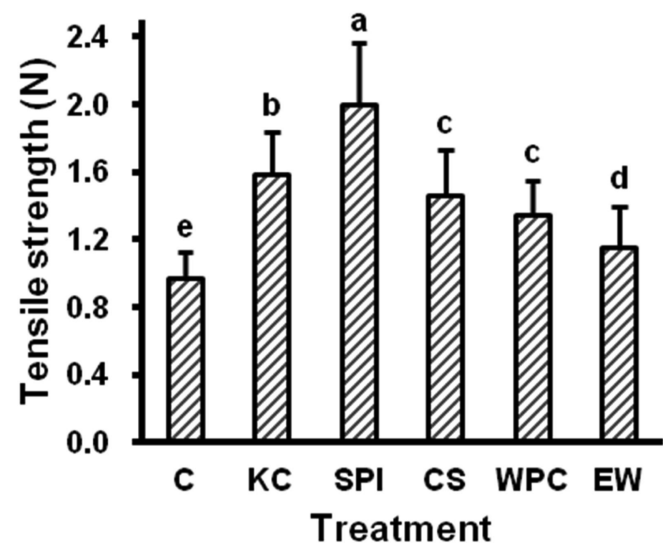

Fig. 1. Effects of non-meat protein binders on the tensile strength of restructured pork prepared by pressurization at $200 \mathrm{MPa}$ for $30 \mathrm{~min}$. The binders used were $\kappa-$ carrageenan (KC), soy protein isolate (SPI), casein (CS), whey protein concentrate (WPC), and egg white (EW). Means with different letters are significantly different $(p<0.05)$.

and thereby to gel formation. Soy globulins exhibit relatively high thermal stability; in particular, the presence of $\mathrm{NaCl}$ stabilizes the globulin structure against thermal treatment (Jiang et al., 2010). On the other hand, globulins in commercial SPI were completely denatured, and denatured globulins are preferred to their native forms for gel formation under appropriate conditions $(\mathrm{pH}$ and temperature) (Feng and Xiong, 2002). Presumably, acidification-induced soy protein gelation gave rise to better binding of meat pieces under high pressure. CS and WPC treatments also improved the tensile strength of meat pieces compared with control $(p<0.05)$, although their impacts were lower than that of SPI $(p<0.05)$. In addition, no difference in tensile strength was observed between CS and WPC treatments. Roesch et al. (2004) reported that WPC was less susceptible to aggregation by GdL compared to SPI. As reported by Pelegrine and Gasparetto (2005), the majority of WPC consists of $\alpha$-lactalbumin and $\beta$-lactoglobulin, and á-lactalbumin is the most stable milk protein against $\mathrm{pH}$ changes. These properties might result in better water-binding properties in restructured pork, but its contribution with GdL to meat binding appears to be limited compared to that of SPI. On the other hand, CS was reported to have better gelation properties than WPC, whereas the presence of $\mathrm{NaCl}$ suppresses the aggregation of CS, thereby showing no difference in tensile strength with WPC treatment (Lucey et al., 1997). Even though it showed good thermal gelling ability (Campbell et al., 2003), EW treatment showed the lowest binding strength among binder treatments $(p<0.05)$. 
Weijers et al. (2006) noted that EW formed a weak and brittle acid-gel because of its fine-stranded microstructure and low degree of disulfide bonding; this is consistent with the present study. In the scope of our experiment, therefore, the results suggest that SPI is the best cold-set meat binder in the presence of GdL and with subsequent pressurization, and that the impact of protein binders on the tensile strength of restructured meat might be dependent on the applied processing conditions and regulated by GdL-induced acidification as well as pressurization.

\section{Microstructure}

Because meat binding is related to protein network formation in the junction zone, one can expect that the better the binding strength, the more intense the integrity of network structure. As shown in Fig. 2, a less intense protein network was exhibited in the control than in KC treatment, which showed a thin and intense network structure inside the junction zone. The results were in accordance with the binding strength; the more intense the network structure, the higher the tensile strength. Meanwhile, protein binders showed different characteristics than the nonmeat proteins $(\mathrm{KC})$, as they formed an amorphous continuum in the meat junctions. It is likely that these proteins filled the spaces between the meat pieces and formed a gel by acidification and pressurization. Therefore, observation of the microstructure did not guaranteed changes in the tensile strength of protein binder treatments, and the factors relating to the tensile strength in the meat pieces were probably the characteristics of the protein gels. In general, SPI gel formation is compromised mostly because of balanced electrostatic interactions, hydrophobic interactions, and disulfide bonds. Comparing the different processing methods, the hydrophobic contribution of pressurization $(\sim 200 \mathrm{MPa})$ is not as high as that of thermal treatment, while pressurization promotes $\mathrm{SH} / \mathrm{SS}$ interchanges among proteins (Messens et al., 1997). Soy glycinin, which constitutes the majority of soy globulin, contains 8 cysteine residues per molecule, compared to 6 residues in ovalbumin and 5 residues in á-lactalbumin (Visschers and de Jongh, 2005). Consequently, the number of reactive residues of SPI might result in the highest tensile strength among the different treatments (Hong et al., 2006). Meanwhile, the presence of $\mathrm{NaCl}$ in the formulation might influence the binding ability of CS and WPC in a different manner. Although CS treatment results in texturized milk proteins (Lucey et al., 1997), electrostatic interactions are important for CS aggregation, and the presence of $\mathrm{NaCl}$ shields charged groups on the $\mathrm{CS}$ particles, decreasing the CS gel forming ability (Lucey and Horne, 2009). Pressurization might promote hydrophobicity and provide cold-set gelling ability of CS, but has limited impact compared to SPI. Alternately, $\mathrm{NaCl}$ enhanced WPC aggregation by enhancing hydrophobic interactions; thus presence of $\mathrm{NaCl}$ was appropriate to texturize WPC (Roesch et al., 2004; Visbinder et al., 2004). The different susceptibilities of CS and WPC to $\mathrm{NaCl}$ were likely resulted from the lack of any difference
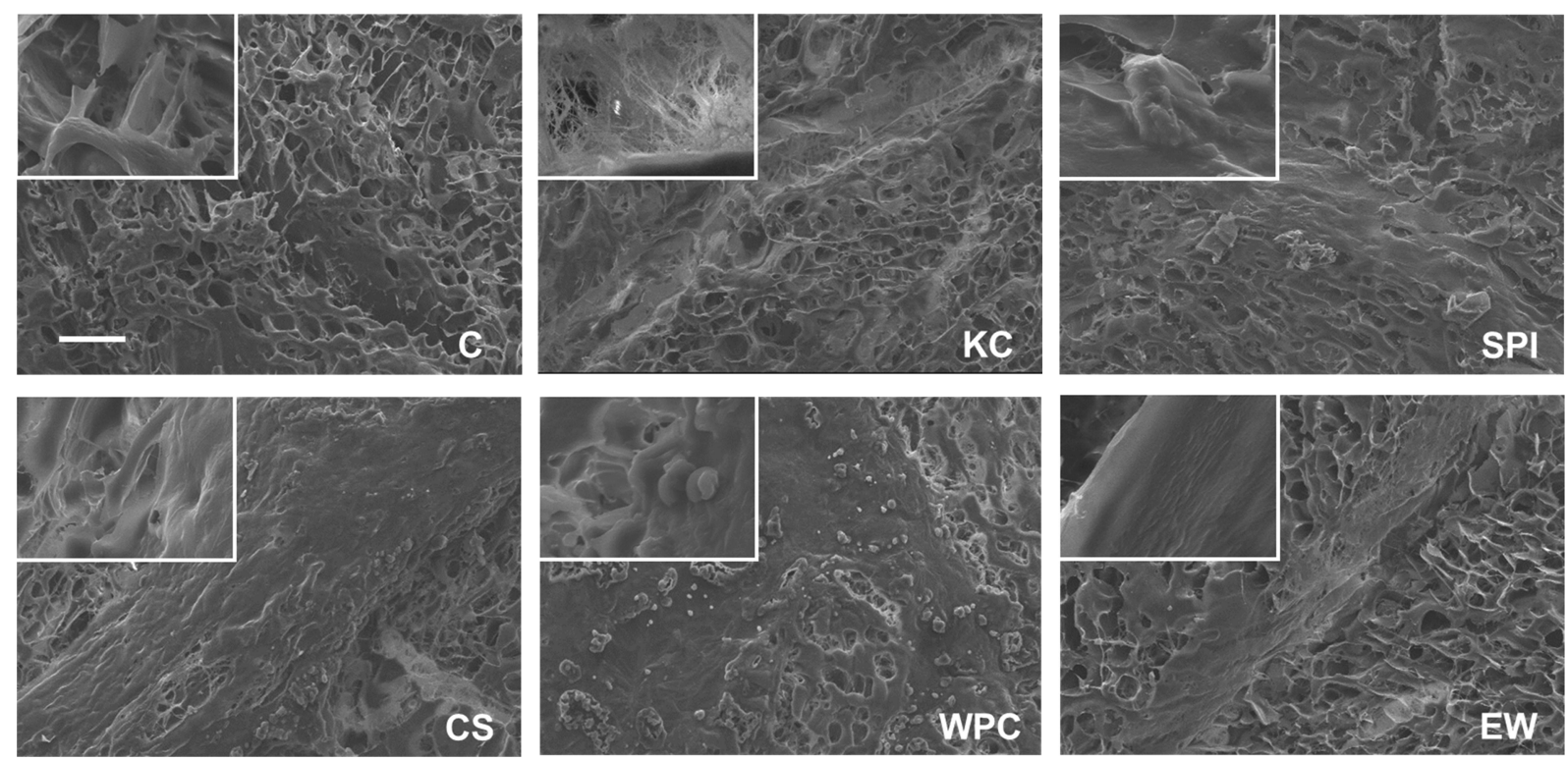

Fig. 2. Microstructure (200×) of the junction zone of restructured pork made without (control, C) and with $\mathrm{K}$-carrageenan (KC), soy protein isolate (SPI), casein (CS), whey protein concentrate (WPC), and egg white (EW). The scale bar indicates 100 $\mu \mathrm{m}$. The insert shows the microstructure at $1,000 \times$ magnification. 
in meat binding after pressurization. Eventually, it was reported that ovalbumin did not undergo denaturation by commercial spray-drying procedures (Campbell et al., 2003), and Hayashi et al. (1989) noted that pressureinduced gelation of $\mathrm{EW}$ required at least $600 \mathrm{MPa}$. In the current study, acidification in the presence of $\mathrm{NaCl}$ reduced the structural stability of EW, subsequently resulting in molecular aggregation; however, the hydrophobic contribution was not as much as those of other protein-based binders (Ichikawa and Shimomura, 2007). The results demonstrate that protein binders, combined with acidification, have a potential advantage in pressure-induced cold-set meat restructuring, even though the binding efficiency is highly dependent on the protein source.

\section{Color}

Compared to the initial color of pork, all treatments showed higher $L^{*}$ and $b^{*}$ values and a lower $a^{*}$ value, mainly due to acidification (Table 3 ). In general, both acidification and pressurization resulted in denaturation of meat proteins, and the meat had a significantly lighter appearance as a result (Hong et al., 2008). It was identified that mild pressurization ( $<350 \mathrm{MPa})$ increased the $a^{*}$ value of meat by reducing the metmyoglobin content (Jung et al., 2003); this increase in $a^{*}$ values was not observed with the different treatments after pressurization in this study, because of acidification. Among the treatments, the addition of protein binders influenced the color of restructured pork; in particular, CS and EW treatments showed the highest $\Delta E(p<0.05)$. The unique color characteristics of different binders would cause differences in color with different treatments (Hong et al., 2006). Finally, the results indicate that the use of protein binders contributed to the color of the final cold-set product; however,

Table 3. CIE color of restructured pork prepared with various binders, glucono- $\delta$-lactone, and pressurization at $200 \mathrm{MPa}$ for $30 \mathrm{~min}$

\begin{tabular}{ccccc}
\hline \hline Treatment $^{1)}$ & $L^{*}$ & $a^{*}$ & $b^{*}$ & $\Delta E^{2)}$ \\
\hline $\mathrm{C}$ & $57.4 \pm 1.04^{\mathrm{ab}}$ & $11.3 \pm 1.03^{\mathrm{ab}}$ & $10.1 \pm 0.33^{\mathrm{c}}$ & $8.59 \pm 1.10^{\mathrm{bc}}$ \\
$\mathrm{KC}$ & $54.8 \pm 0.44^{\mathrm{d}}$ & $11.6 \pm 1.07^{\mathrm{a}}$ & $10.5 \pm 0.60^{\mathrm{c}}$ & $6.11 \pm 0.42^{\mathrm{e}}$ \\
$\mathrm{SPI}$ & $56.6 \pm 0.34^{\mathrm{bc}}$ & $9.9 \pm 0.28^{\mathrm{c}}$ & $11.3 \pm 0.54^{\mathrm{b}}$ & $8.32 \pm 0.29^{\mathrm{c}}$ \\
$\mathrm{CS}$ & $57.8 \pm 0.92^{\mathrm{a}}$ & $10.7 \pm 1.02^{\mathrm{bc}}$ & $12.0 \pm 0.60^{\mathrm{a}}$ & $9.42 \pm 0.83^{\mathrm{ab}}$ \\
$\mathrm{WPC}$ & $55.9 \pm 0.45^{\mathrm{c}}$ & $11.6 \pm 1.00^{\mathrm{a}}$ & $10.1 \pm 0.82^{\mathrm{c}}$ & $7.19 \pm 0.52^{\mathrm{d}}$ \\
$\mathrm{EW}$ & $58.0 \pm 1.73^{\mathrm{a}}$ & $10.3 \pm 0.66^{\mathrm{c}}$ & $11.8 \pm 0.16^{\mathrm{ab}}$ & $9.59 \pm 1.73^{\mathrm{a}}$ \\
\hline
\end{tabular}

${ }^{1)} \mathrm{C}$, control; $\mathrm{KC}, \mathrm{K}$-carrageenan; $\mathrm{SPI}$, soy protein isolate; $\mathrm{CS}$, casein; WPC, whey protein concentrate; EW, egg white

${ }^{2)} \Delta \mathrm{E}$, total color difference based on initial pork color $\left(L^{*}=48.9\right.$, $a^{*}=12.4, b^{*}=9.7$ )

${ }^{\mathrm{a}-\mathrm{e}}$ Means with different superscripts within same column are significantly different $(p<0.05)$ these contributions were not pronounced compared to those caused from pressurization or acidification, since the control showed a relatively high $\Delta E$ ( 9 units).

\section{Acknowledgement}

Financial support for this research was provided by the Brain Korea 21 Project from Ministry of Education and Human Resources Development.

\section{References}

1. Aaslyng, M. D. (2002) Quality indicators for raw meat. In: Meat processing: improving quality. Kerry, J., Kerry, J. and Ledward, D. (eds) Limited and Wood head Publishing, CRC Press LLC, FL, pp. 157-174.

2. AOAC (1990) Official methods of analysis. (15th ed.). Association of Official Analytical Chemists, Washington, DC.

3. Boonyaratanakornkit, B. B., Park, C. B., and Clark, D. S. (2002) Pressure effects on intra- and intermolecular interactions within proteins. Biochim. Biophys. Acta. 1595, 235-249.

4. Bringe, N. A. and Kinsella, J. E. (1990) Acidic coagulation of casein micelles: mechanisms inferred from spectrophotometric studies. J. Dairy Res. 57, 365-375.

5. Bryant, C. M. and McClements, D. J. (1998) Molecular basis of protein functionality with special consideration of cold-set gels derived from heat-denatured whey. Trend. Food Sci. Technol. 9, 143-151.

6. Campbell, L., Raikos, V., and Euston, S. R. (2003) Modification of functional properties of egg-white proteins. Nahrung. 47, 369-376.

7. Chin, K. B., Go, M. Y., and Xiong, Y. L. (2009) Konjac flour improved textural and water retention properties of transglutaminase-mediated, heat-induced porcine myofibrillar protein gel: Effect of salt level and transglutaminase incubation. Meat Sci. 81, 565-572.

8. Dybowska, B. E. and Fujio, Y. (1998) Optical properties of the pre-gel and gel state of soy proteins gelled by GdL under different physical conditions. J. Food Eng. 35, 471-482.

9. Feng, J. and Xiong, Y. L. (2002) Interaction of myofibrillar and preheated soy proteins. J. Food Sci. 67, 2851-2856.

10. Hamm, R. (1986) Functional properties of the myofibrillar system and their measurements. In: Muscle as food. Bechtel, P. J. (ed) Academic Press, Inc., FL, pp. 135-199.

11. Hayashi, R., Kawamura, Y., Nakasa, T., and Okinaka, O. (1989) Application of high pressure to food processing: pressurization of egg white and yolk, and properties of gels formed. Agric. Biol. Chem. 53, 2935-2939.

12. Hong, G. P., Park, S. H., Kim, J. Y., and Min, S. G. (2006) The effects of high pressure and various binders on the physico-chemical properties of restructured pork meat. AsianAust. J. Anim. Sci. 19, 1484-1489.

13. Hong, G. P., Ko, S. H., Choi, M. J., and Min, S. G. (2008) Effect of glucono- $\delta$-lactone and $\kappa$-carrageenan combined with high 
pressure treatment on the physico-chemical properties of restructured pork. Meat Sci. 79, 236-243.

14. Ichikawa, T. and Shimomura, M. (2007) Effects of sodium chloride and other salts on the properties of diluted egg white sols and gels. Food Sci. Technol. Res. 13, 173-177.

15. Jiang, J., Xiong, Y. L., and Chen, J. (2010) pH shifting alters solubility characteristics and thermal stability of soy protein isolate and its globulin fractions in different $\mathrm{pH}$, salt concentration, and temperature conditions. J. Agric. Food Chem. 58, $8035-8042$.

16. Jung, S., Ghoul, M., and de Lamballerie-Anton, M. (2003) Influence of high pressure on the color and microbial quality of beef meat. Lebensm. Wiss. u. Technol. 36, 625-631.

17. Knorr, D., Heinz, V., and Buckow, R. (2006) High pressure application for food biopolymers. Biochim. Biophys. Acta. 1764, 619-631.

18. Kuraishi, C., Sakamoto, J., Yamazaki, K., Susa, Y., Kuhara, C., and Soeda, T. (1997) Production of restructured meat using microbial transglutaminase without salt or cooking. $J$. Food Sci. 62, 488-490.

19. Lucey, J. A., van Vliet, T., Grolle, K., Geurts, T., and Walstra, P. (1997) Properties of acid casein gels made by acidification with glucono- $\delta$-lactone. 1 . Rheological properties. Int. Dairy J. 7, 381-388.

20. Lucey, J. A. and Horne, D. S. (2009) Milk salts: Technological significance. In: Advanced dairy chemistry. Lactose, water, salts and minor constituents (Vol. 3). McSweeney, P. L. H. and Fox, P. F. (eds) Springer, NY, pp. 351-390.

21. Messens, W., Van Camp, J., and Huyghebaert, A. (1997) The use of high pressure to modify the functionality of food pro- teins. Trend. Food Sci. Technol. 8, 107-112.

22. Ngapo, T. M., Wilkinson, B. H. P., and Chong, R. (1996) 1,5Glucono- $\delta$-lactone-induced gelation of myofibrillar protein at chilled temperatures. Meat Sci. 42, 3-13.

23. Pelegrine, D. H. G. and Gasparetto, C. A. (2005) Whey proteins solubility as function of temperature and $\mathrm{pH}$. Lebensm. Wiss. u. Technol. 38, 77-80.

24. Roesch, R., Juneja, M., Monagle, C., and Corredig, M. (2004) Aggregation of soy/milk mixes during acidification. Food Res. Int. 37, 209-215.

25. Shen, J. L. (1976) Solubility profile, intrinsic viscosity, and optical rotation studies of acid precipitated soy protein and of commercial soy isolate. J. Agric. Food Chem. 24, 784-788.

26. Vasbinder, A. J., van de Velde, F., and de Kruif, C. G. (2004) Gelation of casein-whey protein mixtures. J. Dairy Sci. 87, 1167-1176.

27. Visschers, R. W. and de Jongh, H. H. J. (2005) Disulphide bond formation in food protein aggregation and gelation. Biotechnol. Adv. 23, 75-80.

28. Weijers, M., van de Velde, F., Stijnman, A., van de Pijpekamp, A., and Visschers, R. W. (2006) Structure and rheological properties of acid-induced egg white protein gels. Food Hydrocolloid. 20, 146-159.

29. Xiong, Y. L. (2000) Protein oxidation and implications for muscle food quality (Chapter 4). In: Antioxidants in muscle foods: Nutritional strategies to improve quality. Decker, E. A., Faustman, C., and Lopez-Bote, C. J. (eds) John Wiley \& Sons, Inc., NY, pp. 85-111.

(Received 2012.3.24/Revised 2012.5.7/Accepted 2012.5.31) 